\title{
Migrasi Dan Fatherhood: Identitas Dan Perkembangan Karakter Anak Dalam Film Solino
}

\author{
Ardenia Edianti ${ }^{1}$, Lisda Liyanti ${ }^{2}$ \\ ${ }^{1}$ Program Studi Jerman, Fakultas Ilmu Pengetahuan Budaya, Universitas Indonesia \\ ardenia.edianti@ui.ac.id \\ ${ }^{2}$ Program Studi Jerman, Fakultas Ilmu Pengetahuan Budaya, Universitas Indonesia \\ lisda.liyanti31@ui.ac.id
}

Cara Sitasi: Edianti. A., Liyanti. L. (2019). Migrasi Dan Fatherhood: Identitas Dan Perkembangan Karakter Anak Dalam Film Solino. Cakrawala, 19(2), 249-262. Retrieved from doi: https://doi.org/10.31294/jc.v19i2

\begin{abstract}
Migration is not only migrating to another land but most importantly, to the different social and cultural surrounding. This does affect not only identity development but also parenting style. The problem of identity development and parenting in the migrant family is shown in the German movie titled Solino. This movie shows the story of an Italian family who migrated to Germany and faced many identity problems. This research questioned the depiction of how the identity development of migrant children affected by the style of fatherhood. The question will be answered using the qualitative method and literary analysis. Identity development, parenting, and cinematography theories are used to illuminate the scenes in the movie. The result shows that the authoritarian parenting style used by father figure to his children who rise in the egalitarian German society will force the children to rebel. This movie delivers an essential message that migrant parent should open and adopts the right parenting style to raise their children in different social and cultural society.
\end{abstract}

Keywords: Fatherhood, migrant, parenting style, identity

\section{PENDAHULUAN}

Anak-anak yang mengalami kekerasan dari orang tua (secara verbal maupun fisik) masih sering terjadi di masyarakat. Hal ini tidak bisa dianggap remeh, karena kekerasan anak mempunyai dampak yang berkepanjangan bagi sang anak. Berdasarkan laporan "Global Report 2017: Ending Violence in Childhood" sebanyak 73,7 persen anak-anak Indonesia berumur 1-14 tahun mengalami pendisiplinan dengan kekerasan (violent discipline) atau agresi psikologis dan hukuman fisik di rumah (Scholastica, G). Salah satu kasus yang terjadi adalah kekerasan yang dialami seorang anak berinisial SA, berumur 13 tahun, yang diduga menjadi korban penganiayaan oleh bapak kandungnya sendiri. Kasus yang terjadi di Brebes ini tersebar secara viral di media sosial Facebook. Dimuat dalam Pantura Post, viralnya kasus ini pun terdengar oleh Satuan Tugas PPA lewat Facebook, sehingga kasus ini akhirnya ditindaklanjuti. Saat petugas melakukan pendampingan terhadap keluarga korban pada tanggal 16 Maret 2019 di RSUD Brebes, petugas menjelaskan bahwa fisik dan psikis korban mengalami trauma berat (Rahmawan, Y). Kekerasan pada anak yang dilakukan oleh ayahnya ini kembali mengangkat wacana peran ayah dalam keluarga. Menimbulkan pertanyaan, seberapa berpengaruh kah pola asuh ayah yang diterapkan pada anak-anaknya terhadap kondisi anaknya kelak. Berdasarkan pemaparan di atas, hal-hal yang berkaitan dengan peranan seorang ayah dalam keluarga disebut sebagai fatherhood.

Peran ayah sebagai penanggung jawab seringkali hanya berfokus pada tanggung jawab finansial, sehingga mendorongnya untuk lebih mengejar materi agar kondisi ekonomi keluarganya menjadi lebih baik. Salah satu cara yang kerap dilakukan untuk mencari penghidupan yang lebih layak adalah dengan bermigrasi. Ketika bermigrasi, lingkungan yang baru menjadi aspek penting yang akan mempengaruhi perkembangan anak dan pola asuh orang tua, khususnya ayah terhadap anakanaknya. Lingkungan sosial dan budaya dari tempat yang baru juga mempengaruhi pembentukan identitas tiap anggota keluarga. Identitas dapat dipandang dari dua cara, yaitu identity as being yang menjelaskan mengenai jati diri pokok yang mengikat seseorang (seperti asal suku), dan identity as becoming yang menjelaskan identitas seseorang yang diperoleh dan dibentuk seiring waktu (Hall, 1990: 223). Semakin lama seseorang berada di lingkungan yang baru, dapat mempengaruhi perkembangan karakter dan pembetukan identitas seseorang. Berdasarkan Hall, bisa dikatakan bahwa adanya lingkungan yang baru akan memberikan identitas baru terhadap seorang individu kedepannya.

Salah satu film mengenai keluarga yang bermigrasi dari satu negara ke negara lain adalah Solino. Film Solino yang disutradarai oleh Fatih Akin menceritakan keluarga Italia yang pindah ke Jerman tepatnya di Duisburg pada tahun 1964. Setelah 
pindah ke Jerman, sang ayah (Romano Amato) dan ibu (Rosa Amato) membuka restoran pizza bernama Solino yang diambil dari nama kampung halaman mereka. 10 tahun kemudian, anak-anak mereka yaitu Giancarlo Amato dan Gigi Amato tumbuh bekerja di restoran keluarganya tersebut. Dalam berjalannya waktu terjadi banyak konflik dalam keluarga tersebut.

Dalam artikel ini akan dibahas mengenai konsep fatherhood dalam konteks migran yang terdapat di film Solino: Bagaimana penggambaran perkembangan identitas dan karakter anak migrant terkait dengan gaya pengasuhan tokoh orangtua. Adegan-adegan dalam film yang berfokus pada interaksi tokoh ayah dan anak-anaknya akan diteliti lebih dalam. Dalam menganalisis tokoh-tokoh dalam film, relasi antar tokoh akan dijadikan fokus analisis. Hal ini karena hampir sebagian film ini menunjukkan situasi sang ayah yang memiliki beragam konflik dengan anggota keluarganya. Tidak hanya sang ayah, anak-anaknya pun terlihat berkonflik yang secara tidak langsung dipengaruhi oleh kondisi keluarga sejak kecil.

Penulis menemukan beberapa penelitian terkait tema yang berkaitan dengan penelitian di artikel ini. Yang pertama merupakan tesis yang menggunakan film Solino sebagai korpus data yang berjudul "A Changed Image of the 'Immigrant' in German Film? - 'Sense of Belongin' in Fatih Akin's Solino and Gegen die Wand" yang ditulis oleh Eva Finkmeier. Tesis ini menganalisis dua film yang disutradari oleh Fatih Akin, yakni film Solino (2002) dan Gegen die Wand (2004). Kedua film ini terkait dengan tema migrasi dan membahas pandangan film mengenai Jerman sebagai tempat tinggal bagi seseorang dengan latar belakang migran. Dalam film Solino, Finkmeier menjelaskan bahwa kehilangan "rumah" (desa Solino) bukanlah hal yang baik dan tidak dapat mengembangkan identitas seseorang. Jawaban kunci untuk tokoh-tokoh tersebut agar merasa utuh kembali adalah kembali ke kampung halamannya. Sebaliknya, film Gegen die Wand menunjukkan tidak adanya momen untuk kembali ke awal (pulang ke kampung halaman agar merasa utuh kembali) seperti film Solino. Artikel jurnal kedua dan ketiga terkait dengan tema fatherhood, yang menjadi tema bahasan dalam penelitian ini. Artikel kedua berjudul "Relasi Ayah dan Anak dalam Film Oorlogswinter (2008)" yang ditulis oleh Ajeng Larasati. Dalam jurnal ini, Ajeng Larasati menggunakan teknik sinematografi untuk menganalisis relasi ayah dan anaknya. Relasi ayah dan anak digambarkan melalui teknik pengambilan gambar dan diperjelas dengan melalui frame pada setiap adegan dan menunjukkan bahwa tokoh ayah dan anak tidak memiliki komunikasi yang baik dan sering mengalami konflik. Artikel ketiga berjudul "Challenging Masculinity: Father Figure in Disney Pixar's Finding Nemo" yang ditulis oleh Anindya Ramadhan Sadewa Putra. Jurnal ini mengangkat permasalahan figur ayah yang terdapat dalam film tersebut dan berfokus pada bagaimana film Finding Nemo memberikan persepsi berbeda mengenai fatherhood dan maskulinitas pria dalam hal pengasuhan anak melalui tokoh-tokoh Marlin, Gill dan Crush. Berdasarkan telaah penulis, belum ditemukan bahasan mengenai migran dan fatherhood dalam film. Padahal film merupakan media yang cukup efektif untuk menyebarkan dan membentuk opini masyarakat terhadap satu hal. Hal ini yang mendasari penulis untuk mengangkat dengan permasalahan fatherhood dan migrasi dalam film Solino.

\section{METODOLOGI PENELITIAN}

Penelitian ini merupakan penelitian kualitatif. Penulis menggunakan teknik analisa pengambilan gambar sinematografi-videografi oleh Bambang Semedhi (2011) untuk menganalisis maknanya. Semedhi menganggap pengambilan gambar adalah tahap terpenting di dalam proses produksi. Teknik-teknik pengambilan gambarnya antara lain adalah teknik pergerakan gambar (gambar yang dihasilkan pergerakan kamera maupun objek), arah gambar/ screen directio (penjajaran gambar sesuai dengan arah, agar gambar terlihat saling terkait), dan yang terakhir adalah ukuran shot (ukuran gambar untuk menunjukkan ekspresi, gesture, dan pergerakan objek). Selain itu, penulis juga akan mendukung teknik pengambilan gambar tersebut dengan teknik pencahayaan dan tata suara. Penulis akan melakukan studi pustaka untuk mengumpulkan informasi dari berbagai sumber dan menggunakan bahan bacaan pendukung yang sesuai dengan topik penelitian ini, yakni parenting dan pengaruhnya terhadap anak. Landasan teori yang akan digunakan adalah teori gaya pengasuhan (parenting styles) oleh Diana Baumrind (dalam Brooks, 1999) yang dikembangkan oleh Maccoby dan Martin (dalam parentingforbrain.com) mengenai empat gaya pengasuhan yaitu, authoritative, authoritarian, permissive, dan neglectful serta teori faktor perkembangan identitas milik James Marcia mengenai faktor-faktor yang dapat mempengaruhi perkembangan identitas anak. Teori-teori tersebut digunakan untuk menganalisis gaya pengasuhan apa yang digunakan tokoh Romano dan juga dampaknya terhadap identitas dan perkembangan karakter anakanaknya yaitu Gigi dan Giancarlo.

\section{HASIL DAN PEMBAHASAN}

\section{Ruang Sosial Budaya dan Konsep Fatherhood dalam Film Solino \\ Dalam film Solino, tokoh Romano dalam} keluarga sangat berpengaruh dominan terhadap kondisi psikologis anak-anaknya, Gigi dan Giancarlo. Hal ini disebabkan kondisi psikologis dan perilaku anak mencerminkan gaya pengasuhan Romano sejak anak anaknya balita. Untuk menggambarkan 
pertumbuhan anak seiring waktu, Fatih Akin selaku sutradaranya menggunakan alur coming of age. Alur tersebut merupakan alur cerita yang memperlihatkan perkembangan tokoh protagonis dari usia anak-anak hingga dewasa. Film ini menggunakan tiga latar waktu, tepatnya 1964 lalu berlanjut 10 tahun kemudian yaitu 1974 dan kemudian 1984. Film dimulai dengan ditunjukkannya seorang pria dewasa yang sedang memutarkan film di tengah-tengah lapangan yang diisi oleh banyak penonton dengan kursi-kursi layaknya bioskop. Beberapa saat kemudian sang pria meninggalkan lapangan lalu bersandar ke dinding dan mulai merokok. Adegan selanjutnya menunjukkan seorang anak kecil yang ternyata masa kecil pria dewasa tadi yang bernama Gigi Amato. Dalam film ini, Gigi sebagai salah satu tokoh utama akan dianalisa dalam relasinya terhadap ayahnya, yaitu Romano Amato.

Romano Amato merupakan seorang ayah yang menjadi tulang punggung keluarga. Ia merupakan seseorang yang mempunyai watak yang keras terhadap anggota keluarganya, tetapi juga merupakan seseorang yang penyayang karena peduli dengan istrinya dan anak-anaknya. Dalam menjalankan perannya sebagai ayah, menurut Hart (dalam Wijanarko \& Setiawati, 2016) peran-peran ayah adalah sebagai berikut:

a) Economic Provider: yaitu ayah dianggap sebagai pendukung finansial dan perlindungan bagi keluarga.

b) Friends and Playmate: ayah dianggap sebagai "fun parent" serta memiliki waktu bermain yang lebih banyak dibandingkan dengan ibu.

c) Caregiver: ayah dianggap sering memberikan stimulasi afeksi dalam berbagai bentuk, sehingga memberikan rasa nyaman dan penuh kehangatan.

d) Teacher and Role Model: ayah bertanggung jawab terhadap apa saja yang dibutuhkan anak untuk masa mendatang melalui latihan dan teladan yang baik bagi anak.

e) Monitor and Disciplinary: ayah memenuhi peranan penting dalam pengawasan terhadap anak, terutama begitu ada tanda-tanda awal penyimpangan, sehingga disiplin dapat ditegakkan.

f) Protector: ayah mengontrol dan mengorganisasi lingkungan anak, sehingga anak terbebas dari kesulitan dan bahaya.

g) Advocate: ayah menjamin kesejahteraan anaknya dalam berbagai bentuk, terutama kebutuhan anak ketika berada di institusi di luar keluarganya.

h) Resource : dengan berbagai cara dan bentuk, ayah mendukung keberhasilan anak dengan memberikan dukungan di belakang layar.

Interaksi Romano dengan tokoh-tokoh lain berpengaruh dalam penggambaran peran Romano sebagai ayah yang memiliki beragam peran. Peran peran ini akan dijelaskan dalam analisa selanjutnya.
Peran ini terkait juga dengan Parenting Style atau gaya pengasuhan yang diterapkan terhadap anakanaknya. Psikolog Diana Baumrind mengidentifikasi tiga gaya pengasuhan orang tua (dalam Brooks, 1999). Setiap jenis perilaku orang tua memiliki korelasi dengan gaya pengasuhan tertentu, yaitu:

1) Authoritative Parents: orang tua yang mengontrol tegas terhadap perilaku anak tetapi juga menekankan kemandirian dan individualitas pada anak.

2) Authoritarian Parents: atau bisa juga disebut orang tua otoriter yang menggunakan kontrol tetapi dengan cara yang sewenang-wenang dan berorientasi pada kekuasaan tanpa memperhatikan individualitas anak.

3) Permissive Parents: yang menetapkan beberapa batasan pada anak mereka, menerima reaksi anak itu, memberikan kebebasan sebanyak mungkin, tetapi juga sambil menjaga anak tersebut. Orang tua permisif dari luar terlihat kalem dan tidak terlibat. Orang tua ini terkadang membiarkan perilaku anak mereka yang membuat orang tua marah, tetapi mereka tidak merasa cukup nyaman untuk mengungkapkannya.

4) Neglectful Parents: merupakan tipe gaya pengasuhan yang dikembangkan oleh Maccoby dan Martin (1983). Orang tua dengan gaya pengasuhan ini tidak menetapkan batasan tegas atau standar yang tinggi. Mereka cenderung tidak terlibat dalam kehidupan anak, tidak peduli dengan kebutuhan anak-anak mereka dan memiliki komunikasi yang sangat sedikit dengan anaknya. Mereka menawarkan sedikit atau bahkan tidak memberikan aturan ataupun dukungan terhadap anaknya.

Gaya pengasuhan Romano telah digambarkan dari awal film melalui perilaku keras terhadap anak-anaknya. Saat keluarga Amato akan pindah, Romano menyuruh Gigi dan Giancarlo yang sedang menonton film di sebuah atap dengan temantemannya untuk pulang dan segera berkemas ke Jerman.



(06:50) 
Romano memaksa Giancarlo untuk pulang dan menamparnya. Giancarlo kemudian menjawab "Ich werde nicht mitkommen" (06:43) yang berarti "aku tidak mau ikut". Perilaku keras Romano diperkuat dengan adegan dengan teknik kamera medium close up. Menurut Bambang Semedhi (2011), ukuran shot medium close up dimaksudkan untuk menonjolkan mimik atau raut muka seseorang dan untuk menampilkan wajah aktor atau aktris secara utuh. Dalam adegan ini, ukuran shot ini digunakan untuk fokus kepada ekspresi Romano yang menampar Giancarlo dan mengatakan: einfangen"

"Sonst $d u$, willst $d u$ dir noch eine lagi”

"Jika tidak, aku akan menamparmu sekali

Tindakan ini menunjukkan bahwa Romano memiliki gaya pengasuhan dalam kategori Authoritarian Parents yang menuntut kepatuhan mutlak dari anak. Orang tua otoriter memiliki standar yang tinggi dan memiliki beberapa peraturan yang sewenangwenang. Peraturan-peraturan ini tidak pernah dijelaskan mengapa harus diikuti. Dengan menggunakan justifikasi seperti "Peraturan adalah peraturan, ikuti kataku" (Benson, 1968), anak-anak dari orang tua ini diharuskan mengikuti peraturan tersebut. Berawal dari peraturan-peraturan tersebut, bisa dilihat bahwa orang tua otoriter sangat mengontrol setiap aspek dalam hidup anak tersebut karena mereka ingin anaknya bisa mencapai ekspektasinya. Jika anak-anaknya tidak bisa mencapai ekspektasi tersebut, orang tua akan memberlakukan hukuman yang cenderung kasar, bahkan dalam bentuk kekerasan fisik. Selain itu, hukuman dari orang tua juga terkadang meliputi kekerasan psikis seperti membentak, mengeluarkan kata-kata yang melukai anaknya dan menunjukkan perilaku pasif-agresif. Hal ini sesuai dengan perilaku Romano yang membentak dan menampar Giancarlo agar menurut dengannya. Dalam awal film tersebut, Romano tidak meminta persetujuan anggota keluarganya dan terlihat memaksakan keputusannya untuk pindah ke Jerman untuk memulai awal yang baru.

Iming-iming kesuksesan yang akan didapat jika bekerja di Jerman, akhirnya menjadi alasan yang jelas bagi Romano untuk pindah bersama keluarganya. Ketika keluarga Amato sudah sampai di stasiun Duisburg, Jerman, mereka pun sempat bingung dengan kondisi Duisburg yang kontras dari kampung halamannya, Solino.

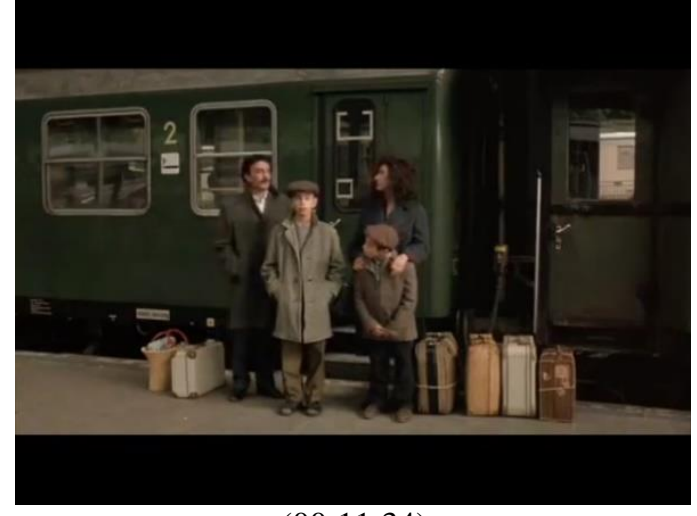

$(00: 11: 34)$

Dalam adegan ini, kamera menggunakan salah satu teknik pergerakan kamera statis, yaitu tilt yang berarti pergerakan kamera ke atas atau ke bawah namun masih tetap bertumpu pada tempatnya (yang hanya bergerak adalah ujung lensanya) (Semedhi, 2011). Hal ini pun didukung dengan teknik kamera long shot yang mana menunjukkan fokus pada lingkungan sekitar sekaligus memperlihatkan reaksi gerak-gerik seluruh keluarga Amato yang kebingungan. Adegan yang diperlihatkan dalam frame tersebut menyajikan gambaran singkat Jerman yang bertolak belakang dengan Solino. Duisburg, Jerman dikiaskan sebagai kota yang kelabu dan kaku sedangkan Solino digambarkan sebagai tempat yang cerah dan hangat. Teknik pencahayaan dalam adegan ini berperan penting dalam menggambarkan suasana Duisburg dengan langitnya yang berwarna kelabu. Selain itu, musik non-diegetic digunakan pada adegan ini. Menurut situs FilmSound.org, suara non-diegetic merupakan sebuah efek suara dalam film yang sumbernya tidak terlihat di layar. Suara non-diegetic juga merupakan suara tersirat yang hadir dalam adegan yang bersumber dari luar cerita film. Petikan gitar yang digunakan dalam adegan tersebut berperan sebagai pendukung suasana dan mendramatisir gestur yang diperlihatkan oleh para tokoh.

Setelah menetap di Dusiburg, Romano bekerja di pertambangan batu bara. Sesuai dengan teori Hall (1990), Pekerjaan baru Romano merupakan identitas baru yang ia dapat (identity as becoming) sebagai salah satu penghuni di kawasan Duisburg, Jerman. Status sosial Romano kemudian berubah menjadi seorang bagian dari kelas pekerja atau buruh. Menurut Pleck (1987), konsep peran ayah pada masa industrialisasi adalah "ayah pencari nafkah" atau disebut "the Breadwinner". Romano termasuk ke dalam kategori ayah "The Breadwinner" karena perannya sebagai pencari nafkah bagi keluarganya. Hal ini diperlihatkan melalui perilaku Romano yang mengejar materi sampai memutuskan untuk bermigrasi ke Jerman dengan keluarganya.

Pertambangan memainkan peranan penting dalam sejarah abad ke-20 Jerman. Pada masa tersebut, industri pertambangan membutuhkan banyak sumber daya manusia. Hal tersebut kemudian 
menjadi pendorong terjadinya migrasi ke Jerman, khususnya daerah Ruhr.

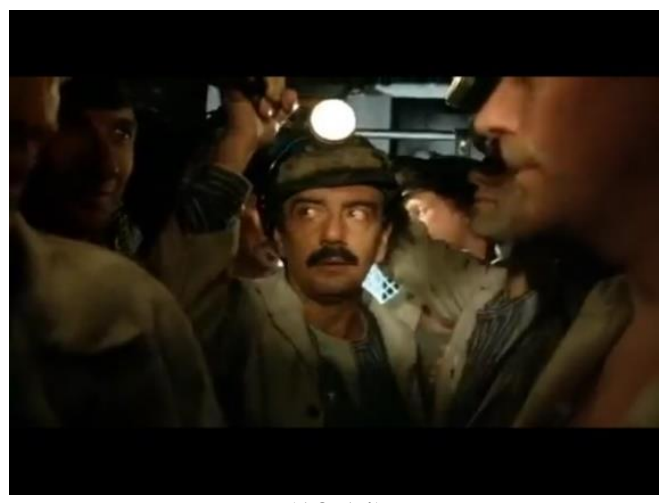

$(13: 14)$

Dalam potongan adegan ketika Romano bekerja di pertambangan, ia terlihat kebingungan dengan situasi sekitarnya. Kamera menggunakan teknik medium close up untuk menekankan ekspresi Romano yang bingung. Hal yang ia alami saat itu terasa sangat asing, sedangkan orang-orang di sekitarnya terlihat sudah terbiasa bekerja di pertambangan tersebut. Keadaan Romano yang belum bisa menerima hal asing tersebut, menyebabkan dia segera keluar dari pekerjaan di pertambangan.

Keadaan yang serupa dengan Romano juga terjadi di adegan selanjutnya. Adegan tersebut memperlihatkan Rosa yang sedang berbelanja bahan makanan di toko bersama Gigi dan Giancarlo. Ketika Rosa melihat kondisi bahan makanan yang dijual toko tersebut, reaksi yang ditunjukkannya adalah terheran-heran.

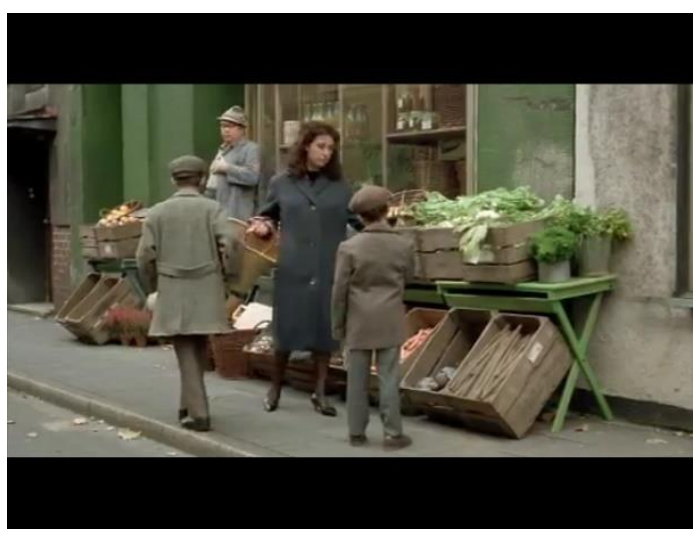

$(14: 00)$

Dalam adegan tersebut, ukuran shot yang digunakan adalah long shot. Menurut Semedhi (2011), ukuran long shot adalah ukuran shot yang memperlihatkan ukuran manusia penuh serta tampak lingkungan sekitarnya. Ukiran ini digunakan untuk menggambarkan kondisi toko tersebut sekaligus memperlihatkan sayuran-sayuran dan bahan makanan lainnya. Sayur-sayuran toko tersebut terlihat layu dan tidak segar, serta variasinya tidak banyak. Ketika Rosa melihatnya, ia berkata kepada anak-anaknya:

"Nicht zu glauben, habt ihr noch mal zu kleine Zwiebel gesehen?"

"Tidak bisa dipercaya, apakah kalian pernah melihat bawang sekecil ini?"

Monolog ini menunjukkan bahwa Rosa tidak suka dengan kualitas bahan-bahan makanan di Jerman yang sangat berbeda dari Italia. Respon anakanaknya terhadap ibunya yang sedang mengeluh berbeda-beda. Giancarlo terlihat seakan-akan tidak peduli dengan pendapat ibunya dan hanya sebatas mengikutinya ke pasar, sedangkan Gigi terlihat mempunyai respon yang lebih baik, yaitu mendengarkan dan terlihat lebih sering berinteraksi dengan ibunya.

Karakter dari Gigi dan Giancarlo sudah jelas terlihat beda dari awal film. Gigi merupakan anak yang baik hati, mudah bergaul, mudah beradaptasi dan selalu penasaran akan suatu hal yang baru, sedangkan kakaknya yaitu Giancarlo adalah anak yang licik, pembohong, dan selalu menjadi pembuat onar. Seperti dalam adegan sebelumnya, Giancarlo juga terlihat diam-diam mencuri bahan-bahan makanan toko tersebut.

Walaupun karakter anak-anak mereka bertolak belakang, kondisi keluarga Amato sebenarnya terlihat hangat pada masa itu. Romano dan Rosa tetap menyayangi anak-anak mereka walaupun mereka juga tidak jarang untuk berselisih dengan satu sama lain. Keduanya tidak segan-segan beradu argumen di hadapan anak-anak mereka. Dalam film ini, konflik yang sering terjadi diantara Romano dan Rosa umumnya berkaitan dengan perbedaan kontras antara Solino dan Duisburg. Konflik keluarga Amato dapat ditinjau dalam adegan di ruang makan berikut.



$(15: 27)$

Romano dan Rosa berargumen di depan anak-anak mereka mengenai Romano yang keluar dari pekerjaannya. Adegan tersebut memperlihatkan Rosa memasak spageti untuk seluruh orang dalam ruangan tersebut. Adegan tersebut kembali 
menekankan adanya kontras antara Jerman dengan Italia. Dalam adegan ini, tokoh Rosa seakan-akan masih ingin menekankan kepada keluarganya bahwa mereka masih orang Italia, walaupun mereka sudah pindah ke Jerman. Ukuran knee shot disuguhkan untuk memperlihatkan keluarga Italia yang menyantap spageti (makanan khas Italia) di sebuah apartemen Jerman. Saat itu alasan Romano keluar dari pekerjaan pertambangan adalah ia tidak ingin tangannya kotor. Rosa pun menjawab

"Dann kann jeder sehen, dass du für deine Familie arbeitest"

"Itu menunjukkan ke semua orang, bahwa kamu bekerja untuk keluargamu."

kalimat yang diucapkan Rosa, secara kias menekankan kembali peran Romano sebagai ayah dan kepala keluarga, yaitu pencari nafkah. Kalimat tersebut juga menekankan status sosial keluarganya yaitu kelas pekerja.

Sebagai tulang punggung keluarga, Romano berusaha mencari pekerjaan lagi dengan melihat lowongan pekerjaan di koran bersama Gigi. Beberapa saat kemudian Rosa melihat sebuah tempat kosong di seberang apartemennya yang bertuliskan “zu vermieten" yang berarti "disewakan". Kemudian Romano dan Rosa memutuskan untuk melihat tempat tersebut bersama anak-anaknya. Saat Rosa dan Romano masih melihat-lihat tempatnya, seorang gadis kecil masuk ke tempat tersebut. Gigi dan Giancarlo sebelumnya telah melihat gadis tersebut ketika mereka sedang duduk di jendela apartemen mereka. Ketika gadis tersebut masuk ke tempat itu, adegan tersebut menunjukkan Gigi mengambil tangan gadis tersebut dan mengajaknya ke lantai bawah. Adegan tersebut menggunakan ukuran shot yaitu knee shot dan juga teknik pergerakan kamera yaitu dolly back. Dolly back merupakan pergerakan kamera menjauhi objek tanpa mengubah ukuran lensa (Semedhi, 2011). Teknik tersebut digunakan untuk memperlihatkan gadis kecil yang berjalan mendekati Gigi dan memperlihatkan tangan Gigi yang menggapai tangan gadis tersebut.

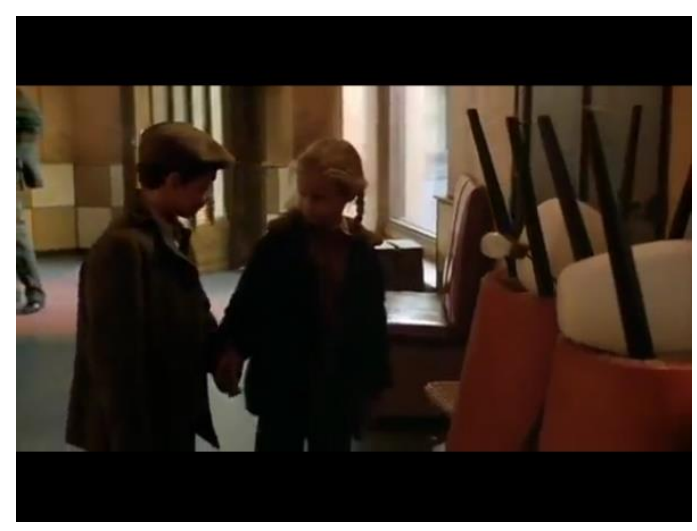

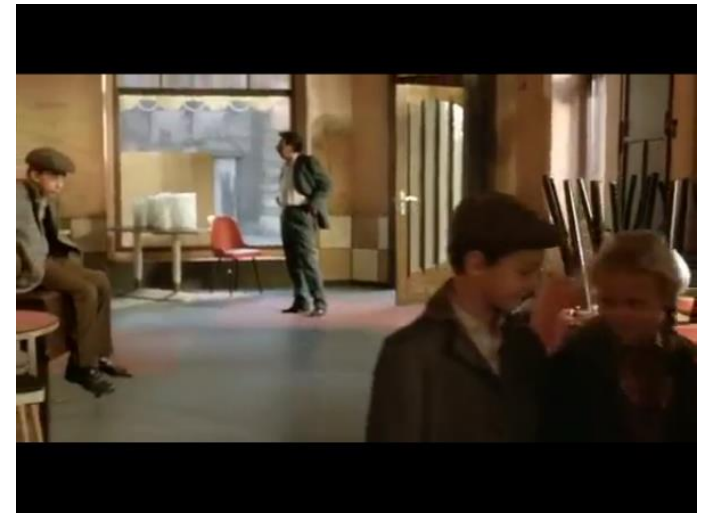

$(20: 30)-(20: 50)$

Selain itu, teknik pergerakan kamera pan left juga digunakan. Menurut Semedhi (2011), teknik kamera pan left merupakan pergerakan kamera ke arah kiri untuk memperlihatkan Giancarlo yang sedang duduk di meja. Posisi kamera pada saat itu memperlihatkan Giancarlo sedang melihat ke arah Gigi dan Jo dan segera pergi keluar. Perasaan iri antar saudara, merupakan hal yang lumrah. Perasaan kesal Giancarlo ketika melihat mereka berdua bukan dilihat dari ekspresinya. Walaupun ekspresi Giancarlo tidak menunjukkan hal tersebut, kamera memberikan ukuran shot "long shot" untuk fokus pada gestur Giancarlo yang pergi keluar, sehingga penonton bisa mengambil kesimpulan bahwa Giancarlo kesal. Dalam adegan tersebut, Giancarlo jarang berbicara dan lebih sering mengekspresikan perasaannya melalui tindakan. Hal ini ditunjukkan ketika Giancarlo menghampiri mereka berdua di lantai bawah dan memukul kepala Gigi agar dapat merebut gadis itu. Hal tersebut menekankan bahwa Giancarlo iri terhadap adiknya yang bisa bergaul dengan gadis tersebut.

Masih di tempat yang sama, Romano dan Rosa akhirnya menyewa tempat kosong tersebut dan menjadikannya sebuah restoran Italia. Romano pun berdiskusi dengan Rosa mengenai nama apa yang akan digunakan sebagai nama Restoran. Beberapa saat kemudian Romano mengusulkan nama "Bei Romano". Usulan Romano termasuk dalam kategori peran ayah, yaitu sebagai pembuat keputusan. Usulan Romano untuk memakai namanya sebagai nama restoran memberikan kesan bahwa ia merupakan orang yang mengutamakan dirinya sendiri. Setelah itu, Rosa kemudian memutuskan Solino menjadi nama restoran mereka. Hal ini menunjukkan bahwa posisi Rosa dalam keluarga Amato tidak semata-mata dipegang hanya Romano, melainkan Rosa juga turut ikut andil dalam membuat keputusan. Rosa "membawa" kampung halamannya ke tengah-tengah wilayah yang baru, yaitu sebuah restoran italia di tengah kawasan industri Duisburg. Bagi Rosa, hal tersebut tentu menjadikan restoran Solino bagaikan sebuah danau di padang gurun.

Di lain pihak, Giancarlo kembali menjahili Gigi dengan merebut box foto miliknya. Ia 
melemparnya hingga rusak, sehingga Gigi segera pergi ke toko kamera yang dahulu ia lihat di sebelah toko sayur. Herr Klasen kemudian membantu memperbaiki kotak tersebut dan berbincang mengenai bidang fotografi dan videografi dengannya. Setelah kembali ke restoran tersebut, Romano bertanya kepada Gigi

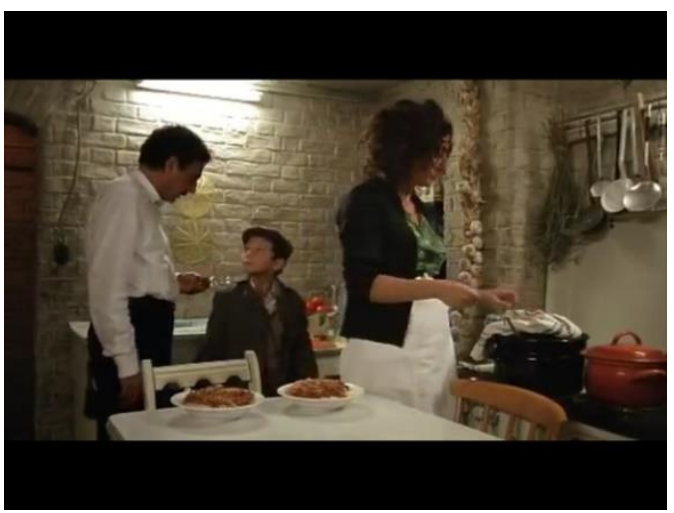

$(27: 24)$

"Wo bist du die ganze Zeit gewesen?"

"Di mana kamu selama ini?"

ia bertanya kepada Gigi sambil menamparnya. Rosa yang sedang berada di sebelahnya tidak melakukan apapun dan menghiraukannya. Reaksi Gigi yang diam saja ketika ditampar menunjukkan bahwa kekerasan fisik terhadap anak sudah dianggap sebagai hal yang lumrah oleh keluarga tersebut.

Melihat adanya kekerasan fisik dan psikis merupakan hal yang lumrah, Gigi tidak pernah terlihat sedih dan menangis. Gigi setidaknya tetap memaklumi perbuatan ayahnya dan mulai menemukan pengalih baginya, yaitu ketertarikannya pada film. Ia membantu seorang sutradara film Italia bernama Salvatore Baldi untuk meneruskan adegan film Jerman yang sebelumnya tidak bisa dilakukan karena kekurangan rel. Sosok Baldi direpresentasikan sebagai simbol akulturasi budaya antara Italia dan Jerman. Seorang sutradara Italia membuat film bertemakan Nazi dari Jerman merupakan kontras antar kedua negara lainnya yang disajikan di dalam film ini. Hal tersebut bahkan ditekankan ketika Baldi dan anggota kru filmnya yang merupakan orangorang Jerman sering terlihat makan siang di restoran Solino yang merupakan restoran Italia. Dengan adanya sosok Baldi, ia kemudian menjadi figur idola bagi Gigi dan kemudian menginspirasinya untuk menjadi sutradara Italia di Jerman seperti Baldi. Sayangnya keinginannya untuk menekuni bidang film dilarang oleh Romano. Larangan Romano ditekankan melalui adegan ketika Gigi dituduh mencuri. Gigi bersikeras bahwa ia tidak mencuri dan pada akhirnya, Romano melarang Gigi untuk bergaul lagi dengan orang-orang film tersebut.



(37:11)

"Du willst mir wohl mein Geschäft ruinieren? Ich will dich nicht aber diesen Film Leuten sehen. hast du mir verstanden?"

"Apakah kamu ingin menghancurkan bisnisku? Aku tidak mau kamu bertemu dengan orang-orang film tersebut lagi. Apakah kamu mengerti?"

Sikap Romano yang sampai menarik kerah baju Gigi menunjukkan bahwa ia sangat memperdulikan bisnisnya daripada mencari tahu apakah Gigi benarbenar mencuri atau tidak. Menurut Lamb (2010), secara umum proses migrasi membuat para ayah menghadapi tantangan dalam membentuk identitas baru dan mengintegrasikannya ke dalam identitas lama. Hal ini menunjukkan bahwa proses migrasi menyebabkan Romano mengalami tantangan untuk membentuk identitas baru. Adegan tersebut menunjukkan Romano ingin mempunyai status baru, yaitu menjadi orang yang terpandang dalam lingkungan sosial di Jerman. Ia mementingkan kelangsungan restorannya daripada anaknya. Hal ini pun ditekankan melalui ukuran shot full shot yang membelakangi Gigi untuk menunjukkan betapa dominannya Romano sebagai ayah yang membentak Gigi. Selain itu, Romano juga menampar Gigi dan melontarkan kalimat menyakitkan bagi Gigi hingga menangis. Gigi menangis karena ketika akhirnya ia menemukan sesuatu yang disuka, sang ayah justru melarangnya.

"So eine uns sehen, du musst zur Schule gehen, verstehst du?"

"Lihat kita, kamu seharusnya pergi ke sekolah, apakah kamu mengerti?”

"So eine uns sehen" kata-kata yang dilontarkan Romano mengandung kiasan seperti ingin berkata "inilah film mu" dan kemudian menamparnya. Hal tersebut memperlihatkan bahwa Romano memberikan gestur kepada Gigi agar ia sadar bahwa ketertarikannya pada film itu tidak berguna dan lebih penting untuk bersekolah. Menurut Brooks (1999), orang tua yang berada di kelas pekerja lebih mementingkan kepatuhan pada anak dan cenderung menggunakan kekuatan-asertif untuk memaksakan kepatuhan, lalu mereka juga cenderung 
lebih sering menggunakan kekerasan fisik dan menyatakan "karena aku bilang seperti itu". Perilakuperilaku yang telah dilakukan Romano menunjukkan, bahwa Romano mempunyai gaya pengasuhan authoritarian dan menggunakan kekuasaannya melalui kekerasan fisik dan psikis agar anakanaknya patuh.

\section{Pengaruh Fatherhood dan Perkembangan Identitas serta Karakter Anak Migran dalam Film Solino}

Setelah bermigrasi ke Jerman, peran Romano sebagai ayah dipengaruhi oleh lingkungan sosial dan budaya Jerman yang berbeda dari sebelumnya. Romano yang memiliki status sosial kelas pekerja mulai mengincar status yang lebih tinggi dalam kelas sosial di Duisburg. Restorannya semakin sukses dan membuatnya semakin mengejar materi dan lebih mementingkan usahanya daripada keluarganya. Adanya budaya baru yang diadopsi oleh anak anak tidak terlalu disadari oleh Romano yang sibuk dengan bisnisnya. Hal ini diperparah dengan ironi yang terjadi pada diri Romano. Upayanya untuk naik pada status kelas menengah di Jerman tidak membuatnya mengerti atau peka pada perbedaan budaya lingkungan yang ada disekitarnya. Ia tetap pada gaya pengasuhannya yang otoriter. Hal ini memberikan dampak pada perkembangan pembentukan identitas pada Gigi dan Giancarlo. Menurut Marcia (1993), perkembangan pembentukan identitas diri dapat dipengaruhi oleh berbagai faktor, yaitu:

a) Tingkat identifikasi dengan orang tua pada masa sebelum dan selama masa remaja.

b) Gaya pengasuhan dari orang tua.

c) Adanya seseorang yang dianggap sebagai role model.

d) Harapan sosial mengenai identitas pilihan dari keluarga, sekolah dan teman sebayanya.

e) Sejauh mana keterbukaan seseorang terhadap identitas alternatif lainnya.

f) Sejauh mana kepribadian pada masa praremaja menyediakan landasan yang tepat untuk

mengatasi masalah identitas.

Pembentukan identitas Gigi dan Giancarlo sangat dipengaruhi oleh identifikasi terhadap orang tuanya yaitu Romano dan Rosa. Perilaku dari orang tua merupakan sumber identifikasi dan kelak akan menjadi bagian dari identitas mereka. Romano dan Rosa diidentifikasi sebagai pasangan suami istri yang bertolak belakang, ayahnya dengan sifat yang keras sedangkan ibunya digambarkan lebih lembut. Gaya pengasuhan juga memainkan peranan penting karena orang tua merupakan sumber informasi dan figur bagi anak. Oleh karena itu, perkembangan karakter
Gigi dan Giancarlo sangat dipengaruhi oleh sikap dan perilaku orang tua dalam mengasuh mereka.

10 tahun kemudian pada tahun 1974, Restoran keluarga Amato semakin sukses dan selalu dipadati pengunjung. Gigi dan Giancarlo membantu usaha keluarga tersebut dari kecil hingga mereka beranjak remaja. Suatu saat, Romano mengajak Gigi dan Giancarlo untuk berbicara mengenai perkuliahan Gigi. Romano menginginkan Gigi untuk berkuliah agar suatu saat Gigi dan Giancarlo bisa membuka restorannya sendiri. Gigi menolak karena ia ingin melanjutkan impiannya yaitu menekuni bidang film.

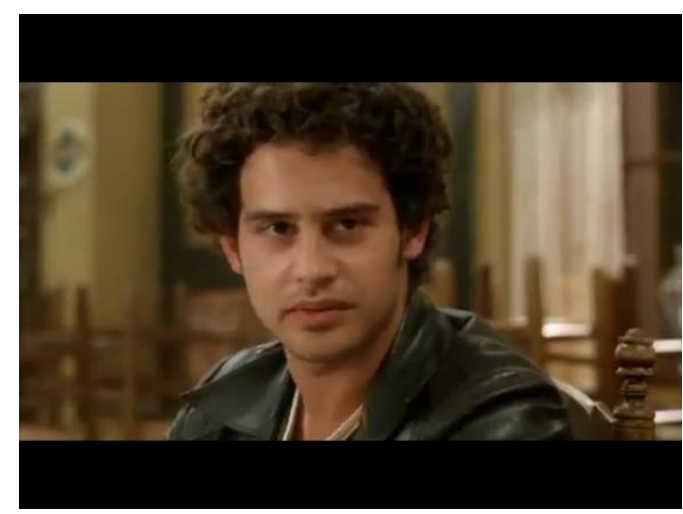

(42:01)

Giancarlo kemudian angkat bicara bahwa ia dan Gigi tidak pernah dibayar oleh Romano selama ini. Pada saat itu, Giancarlo yang saat kecil memiliki karakter yang selalu diam, mengalami perkembangan karakter seiring waktu. Ia mulai berani mengutarakan pendapatnya pada Romano dengan cara mengkritiknya dan menampilkan gestur perlawanan, yaitu dengan cara berbicara dan menatap lurus ayahnya yang memicu kemarahan Romano. Hal ini didukung dengan ekspresi Giancarlo yang memperlihatkan ia kesal dengan sifat egois Romano. Sedangkan Gigi, walaupun ia juga menunjukkan penolakan dengan mengutarakan pendapat ia tidak ingin kuliah, Gigi masih menunjukkan gestur patuh dengan hanya mendengarkan pendapatnya serta hanya menjawab seperlunya. Sebelumnya terlihat bahwa mereka bekerja murni untuk membantu keluarga, namun uraian dari Giancarlo menggeser konteks tersebut menjadi kekerasan anak dalam bentuk eksploitasi anak. Setelah itu, sifat otoriter Romano pun diperlihatkannya lagi setelah 10 tahun kemudian, yaitu dengan mengatakan:

"Wir sind eine Familie, und deshalb musst du das tun was ich dir sage!"

"Kita satu keluarga, dan itulah mengapa kamu harus melakukan apa yang saya katakan!"

Romano menekankan nada bicaranya pada kalimat tersebut untuk menegaskan posisinya sebagai seseorang yang memiliki kekuasaan terhadap anakanaknya. 
Akibat dari gaya pengasuhan Romano, dampak pertama yang ditunjukkan adalah perilaku Gigi dan Giancarlo yang memberontak dan mencar kebebasan. Hal ini digambarkan pada adegan ketika mereka berpesta minuman keras dan narkoba dengan teman-temannya di apartemen mereka.

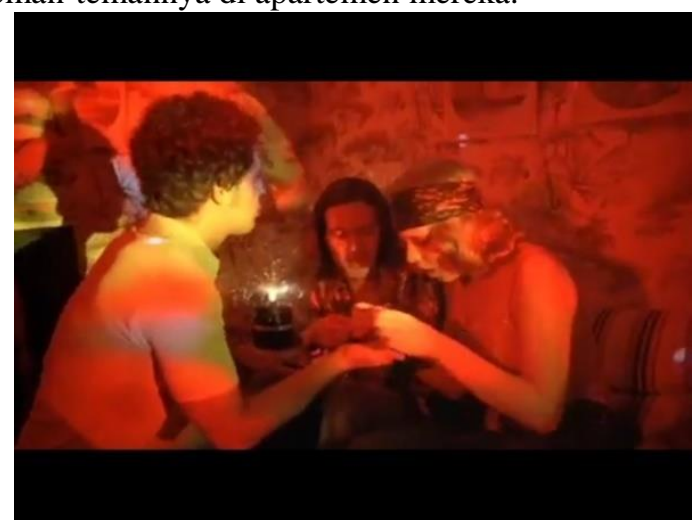

(43:48)

adegan tersebut menunjukkan teknik pergerakan kamera pan yang menyapu sekitar apartemen untuk memperlihatkan pestanya. Perilaku Gigi dan Giancarlo terlihat lebih bebas ketika tidak ada kehadiran orang tua mereka. Gaya asuh otoriter Romano menyebabkan Gigi dan Giancarlo sering mendapatkan larangan. Ketika Romano tidak ada di sekitar mereka, mereka bisa menyentuh kebebasan yang selama ini jarang didapat.

Perilaku yang ditunjukkan oleh Gigi dan Giancarlo tidak semata-mata disebabkan oleh Romano saja, melainkan lingkungan sosial. Kedua anak tersebut tumbuh besar di Duisburg, sehingga teman sebaya memainkan peranan penting terhadap perkembangan karakter mereka. Dalam film ini, teman sebaya yang paling mempengaruhi perkembangan karakter Gigi dan Giancarlo adalah teman masa kecilnya di Jerman yaitu Jo. Jo merupakan gadis kecil yang menghampiri Gigi dan Giancarlo di restoran ketika mereka kecil. Dalam pesta sebelumnya juga diperlihatkan banyak teman sebaya mereka yang merepresentasikan lingkungan sosial sekitar Gigi dan Giancarlo. Berdasarkan hal tersebut, dapat diambil kesimpulan bahwa lingkungan sosial di Jerman digambarkan memiliki pergaulan yang bebas dan sangat terbuka. Sesudah melakukan migrasi ke Jerman, identitas Gigi dan Giancarlo sebagai orang Italia mengalami pergeseran. Hal ini sesuai dengan teori Marcia mengenai perkembangan identitas, yaitu faktor adanya harapan sosial mengenai identitas pilihan teman sebayanya serta faktor tingkat keterbukaan seseorang terhadap identitas alternatif. Pergeseran identitas ditunjukkan dengan adanya identitas alternatif yang didapat, yaitu Gigi dan Giancarlo yang sedang melakukan suatu hal yang berasosiasi dengan budaya Jerman, yakni melakukan pergaulan bebas karena adanya pengaruh teman sebaya. Dalam film ini, Italia digambarkan memiliki lingkungan sosial yang lebih konservatif, sedangkan Jerman terbuka. Oleh karena itu, perilaku Gigi dan Giancarlo tersebut merupakan bentuk penyesuaian mereka terhadap lingkungan sosial Jerman yang lebih terbuka.

Romano dan Rosa melihat pesta di apartemennya serta kondisi Giancarlo dan Gigi yang berada di pengaruh narkoba. Hal ini menyebabkan Romano murka, sehingga ia membentak dan memukuli anak-anaknya. Berdasarkan hal tersebut, dapat disimpulkan bahwa setelah 10 tahun, konflik semacam itu masih sering terjadi dalam keluarga Amato. Adanya berbagai macam konflik yang secara konstan terjadi, menimbulkan situasi emosional yang buruk bagi keluarga dan dapat mempengaruhi perkembangan anak.

Dampak kedua gaya asuh dari Romano adalah adanya peningkatan agresi dalam diri anak. Di antara Gigi dan Giancarlo, Gigi memperlihatkan perkembangan karakter yang cukup pesat pada rentang waktu 10 tahun yaitu 1964 hingga 1974.



$(57: 26)$

Adegan tersebut menggunakan ukuran shot long shot untuk memperlihatkan situasi dari latar tempat dapur dan gestur Gigi yang menyilangkan tangannya di atas meja. Ia ingin membicarakan gaji dengan ayahnya, lalu Romano menjawab: sprechen'”

$$
\text { "Ich muss über gar nicht zu mit dir }
$$
denganmu"

"tidak ada yang perlu dibicarakan

lalu Gigi merespon bezahlen?"

"Warum kannst du mich nicht normal pantas?"

"Mengapa kau tidak membayarku secara

Dari dialog tersebut, bisa kita lihat bahwa Gigi bukan hanya mengutarakan pendapatnya, tetapi ia menunjukkan inisiatif dengan memulai pembicaraan terlebih dahulu. Sebelumnya Gigi mengutarakan pendapatnya hanya sebagai bentuk pembelaan diri ketika Romano menyuruhnya kuliah. Alasan Gigi membicarakan gaji dengan ayahnya adalah karena ia ingin membeli sebuah kamera, tetapi Romano masih tidak suka dengan ketertarikan Gigi 
terhadap film. Setelah Romano menolak permintaan Gigi, amarah Gigi meluap dan kemudian membanting panci yang berada di sebelahnya.

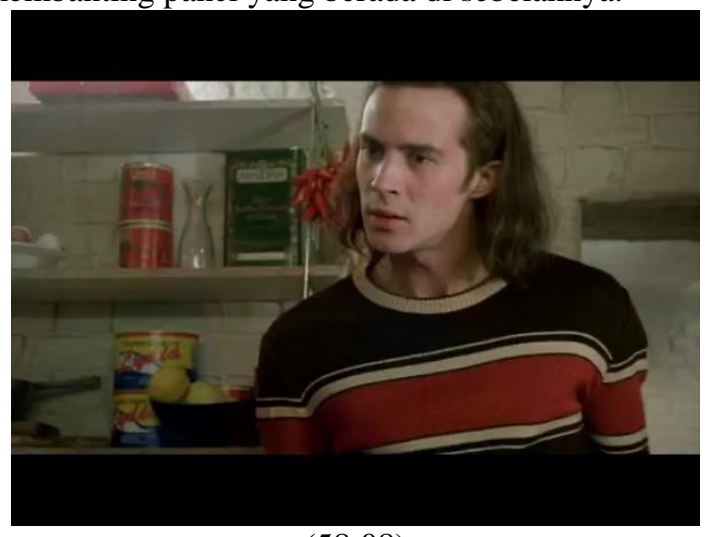

(58:08)

Dengan ukuran shot medium close up, shot tersebut menekankan pada adegan Gigi yang membentak Romano serta memfokuskan pada ekspresi marah yang diperlihatkan Gigi. Ia pun membentak kepada ayahnya:

"Ich arbeite dafür! Ich will diese Kamera, Ich will Filme machen!

"Aku bekerja untuk itu! Aku ingin kamera ini, aku akan membuat film!”

Intonasi tinggi yang diucapkan dari kalimat tersebut menunjukkan emosi Gigi yang memuncak dan menunjukkan bahwa ia merupakan orang yang memendam segala keluh kesahnya. Oleh karena itu, emosi Gigi yang dipendamnya selama ini akhirnya mencapai puncaknya dan akhirnya ia melakukan agresi terhadap ayahnya. Dalam adegan ini, panci tersebut terlihat di dalam frame dan memperlihatkan perbuatan yang dilakukan Gigi sebagai bentuk agresi. Berdasarkan adegan tersebut, bentuk agresi yang ditunjukkan Gigi tidak ditujukan untuk menyakiti Romano secara fisik, melainkan untuk mengekspresikan kekesalannya yang memuncak. Panci yang dijatuhkan Gigi merupakan simbol restoran yang dikelola Romano, sehingga perilaku Gigi merupakan ekspresi kekesalannya terhadap restoran yang menyebabkan Romano buta akan kesuksesan dan tidak peduli lagi pada keluarganya.

Situasi emosional keluarga yang tidak baik juga berdampak terhadap hubungan anak dengan saudara kandungnya sendiri. Menurut Kendrick dan Dunn (dalam Benson, 1968:257), anak-anak yang mengalami interaksi negatif dengan orang tua mereka dapat melakukan imitasi saat melakukan interaksi terhadap saudara kandungnya sendiri. Agresi yang dilakukan oleh Gigi dan Giancarlo merupakan bentuk imitasi terhadap Romano. Ketika Gigi menginginkan sebuah kamera, Giancarlo berinisiatif untuk membantunya mendapatkan kamera dan memutuskan untuk mencurinya bersama Gigi. Saat itu ia menyuruh Gigi untuk mencuri uang di kasir, kemudian ia kabur meninggalkan Gigi ketika polisi datang. Akibatnya, hanya Gigi yang tertangkap oleh polisi. Ketika ia keluar dari penjara, Romano yang murka menendang Gigi. Melihat kejadian tersebut, Giancarlo segera berlari untuk mencegah kekerasan oleh Romano. Perkembangan karakter Giancarlo ditunjukkan ketika ia berlari ke arah mereka lalu mendorong Romano. Perbuatan yang dilakukannya merupakan sebuah bentuk perlindungan terhadap Gigi, tetapi juga sebuah bentuk perlawanan terhadap Romano. Perlawanan tersebut ditunjukkan melalui adegan Giancarlo yang menggunakan kontak fisik sama seperti Romano yang selalu menggunakan kontak fisik agar anakanaknya patuh. Semasa kecil, ia tidak pernah terlihat sekalipun melindungi Gigi ketika Gigi dimarahi oleh Romano. Oleh karena itu, adegan tersebut merupakan adegan penentu Giancarlo mengalami perkembangan karakter.

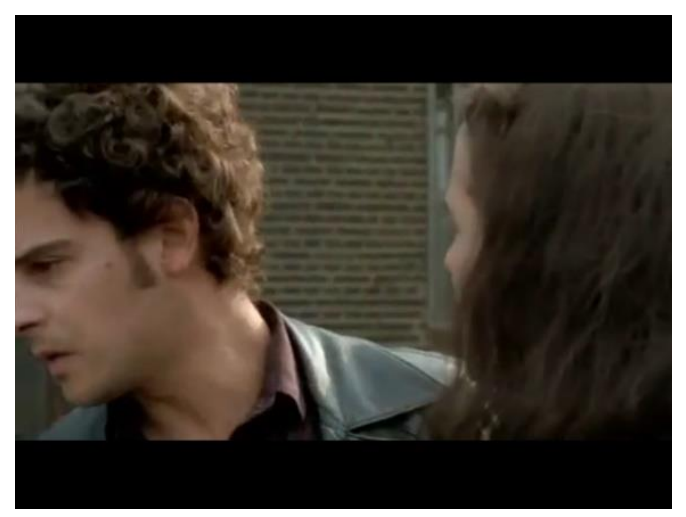

$(1: 01: 11)$

Secara mengejutkan, Gigi pun juga melakukan imitasi terhadap ayahnya. Ketika kamera yang dicuri Giancarlo dan Gigi diuangkan oleh Giancarlo, Gigi pun akhirnya menampar Giancarlo. Perilaku tersebut sesuai dengan teori Kendrick dan Dunn sebelumnya mengenai imitasi yang dilakukan anak terhadap saudara kandungnya sendiri. Semasa kecil Gigi selalu ditampar oleh Romano, sehingga 10 tahun kemudian, Gigi juga melakukan hal serupa pada saudara kandungnya sendiri. Dengan ukuran shot close up, adegan tersebut berfokus pada perbuatan Gigi yang menampar kakaknya. Ketika Giancarlo ditampar, ia pun juga melakukan hal yang serupa, yaitu membenturkan kepalanya kepada kepala Gigi, sehingga dapat diambil kesimpulan bahwa bentuk imitasi yang dilakukan kedua anak tersebut yang pertama adalah melakukan kekerasan fisik.

Setelah insiden tersebut, Gigi justru mendapat kamera dari Herr Klasen, sosok yang mengenalkan Gigi pada dunia film saat ia kecil. Gigi kemudian membuat film pertamanya yang berjudul "Das ist jetz wech" yang berarti "Sekarang Semua Sudah Hilang". Sesuai dengan teori Marcia sebelumnya, yaitu perkembangan identitas karena adanya figur idola. Sebelumnya, figur idola bagi Gigi 
merupakan seorang sutradara yang bernama Signor Baldi. Hal ini menunjukkan bahwa identitas Gigi yang didapat kelak sebagai seorang sutradara film merupakan hasil dari kekagumannya pada Signor Baldi.

Setelah beberapa waktu, Rosa pun mengidap leukemia dan akhirnya memutuskan untuk kembali ke Solino. Ketika Gigi di Solino, ia mendapat kabar dari Giancarlo bahwa filmnya masuk festival film "Ruhrfilmtage”. Ketika Gigi meminta Giancarlo untuk menjaga ibunya di Solino, sekali lagi Giancarlo mengingkari janji tersebut dan tidak datang. Akibatnya, Gigi tidak dapat hadir pada penghargaan film "Ruhrfilmtage". Kehadiran Gigi pada akhirnya digantikan oleh Giancarlo. Ketidakhadiran Giancarlo di Solino mengindikasikan bahwa ia tidak ingin kembali ke kampung halamannya. Walaupun Gigi sudah memohon kepadanya, Giancarlo tetap enggan untuk kembali ke Solino. Hal ini merepresentasikan bahwa Giancarlo telah membuang identitasnya sebagai orang Italia dan lebih memilih identitas barunya, yaitu sebagai orang Jerman.

Dampak gaya asuh yang ketiga adalah adanya masalah perilaku. Giancarlo merupakan karakter yang licik. Karakteristik ini diperkuat dari perilakunya yang suka mencuri dan berbohong untuk mendapatkan apa yang ia inginkan. Karakter licik ini digambarkan pada adegan ketika Giancarlo berbohong pada publik bahwa ia adalah Gigi yang memenangkan piagam penghargaan Ruhrfilmtage. Alih-alih ia mengoreksi bahwa dirinya bukanlah yang membuat film tersebut, ia justru tetap memainkan peran sebagai Gigi.

Masalah perilaku dari Gigi dan Giancarlo ditonjolkan pada beberapa waktu kemudian. Ketika Gigi kembali ke Duisburg, ia pun terkejut melihat Giancarlo dan Jo tidur bersama.

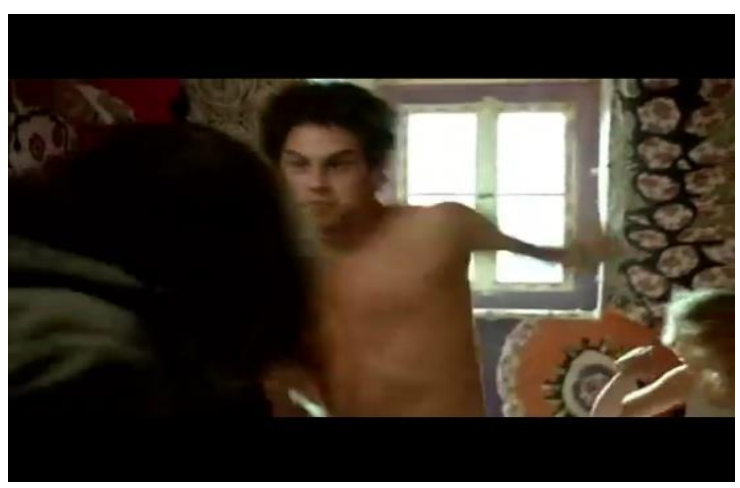

$(1: 30: 11)$

Kamera juga menggunakan point of view dari pintu kamar untuk memperlihatkan adegan perkelahian antar kakak dan adik tersebut. Dalam adegan ini, Gigi yang dari kecil digambarkan sebagai sosok yang lemah menunjukkan dominasinya terhadap Giancarlo. Ia memulai perkelahian tersebut dan terus memukuli Giancarlo yang pada akhirnya hanya bisa berlindung. Ayahnya yang sering melakukan kekerasan fisik terhadap mereka berdua menyebabkan Gigi dan Giancarlo menganggap hal itu lumrah dilakukan, sehingga mereka berdua tidak segan-segan untuk saling memukul walaupun mereka berdua merupakan saudara kandung.

Setelah perkelahian tersebut, Jo mengobati luka Giancarlo sambil berbincang. Keinginan Giancarlo untuk sukses merupakan imitasi sifat ayahnya yang menghalalkan segala cara untuk sukses. Alasan Giancarlo melakukan itu disebabkan sifat irinya terhadap Gigi yang selalu berhasil.

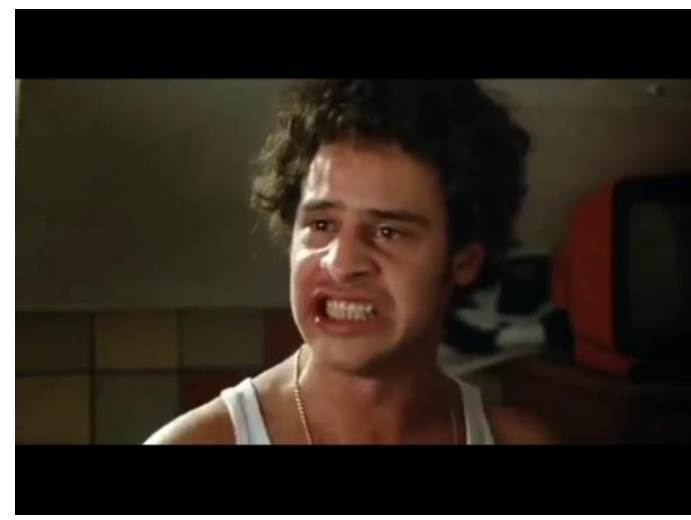

$(1: 32: 08)$

Pada adegan tersebut, teknik kamera medium close up juga digunakan untuk menonjolkan ekspresi sakit hati Giancarlo yang mengatakan:

"Einmal geht es um mich, verstehst du, geht es um mich mich mich!"

"Sekali ini, semuanya tentang diriku, apa kau mengerti, semuanya tentang diriku, diriku, diriku!"

Kalimat tersebut diucapkan Giancarlo sambil menangis, yang menunjukkan bahwa ia sudah muak tidak diakui oleh orang-orang. Orang tuanya sendiri bahkan tidak mengakui dirinya, sehingga Giancarlo kurang menghargai dirinya sendiri. Sebelumnya ketika Romano menyuruh Gigi untuk kuliah, Romano sempat membandingkannya pada Gigi yang lebih pintar darinya dan membuat Giancarlo merasa kecil hati. Menurut Brooks (1999) anak-anak dari orang tua yang otoriter akan menjadi tidak bahagia dan akan kesulitan untuk mengekspresikan perasaannya. Selama film ini, dari masa kanak-kanak jarang sekali terlihat momen ketika Giancarlo mengekspresikan perasaannya, namun dalam adegan tersebut Giancarlo akhirnya mengutarakan perasaannya yang sebenarnya di hadapan Jo sambil menangis. Terbentuknya karakter kurang menghargai diri sendiri dan terlihat kurang percaya diri dari Giancarlo merupakan dampak terakhir dari gaya pengasuhan Romano.

Setelah masalah Giancarlo, masalah Gigi pun muncul ketika ia sudah putus asa mengenai siapa yang akan menjaga ibunya di Solino. Ia mendatangi Romano dan memintanya untuk kembali ke Solino tetapi Romano tidak mau. Emosi Gigi pun 
memuncak karena Romano seakan-akan mencari alasan untuk tidak kembali ke Solino. Menurut Eron, Walder, et al., dalam Benson (1968), ketika anak laki-laki dihukum berat, efek frustasi dari hukuman tersebut tampaknya akan menjadikan mereka lebih agresif daripada yang seharusnya. Sesuai dengan teori tersebut, tindakan Romano yang sering melakukan kekerasan menyebabkan Gigi dan Giancarlo mempunyai perilaku agresif. Kali ini Gigi menunjukkan dominasinya terhadap Romano, sosok yang selama ini memegang otoritas terhadap hidupnya. Pada adegan tersebut, Gigi menaikan intonasinya kepada Romano dan berkata:

"Was sollen sie denn nicht hören? dass du deine Frau betrogen hast?"

"Apa yang seharusnya mereka tidak dengar? bahwa kau mengkhianati istrimu?" (1:33:04)

Saat monolog tersebut berlangsung, Pelanggan restoran tersebut kemudian melihat Gigi yang membentak ayahnya. Intonasi Gigi yang naik menunjukkan bahwa ia sengaja mengatakan kalimat tersebut keras-keras agar seluruh pelanggan di restoran bisa mendengar fakta bahwa ayahnya selingkuh. Kalimat yang diucapkan Gigi menyulut amarah Romano dan segera berdiri untuk memukul Gigi. Gigi yang hampir dipukul, secara reflek langsung mendorong Romano hingga mengenai lemari.

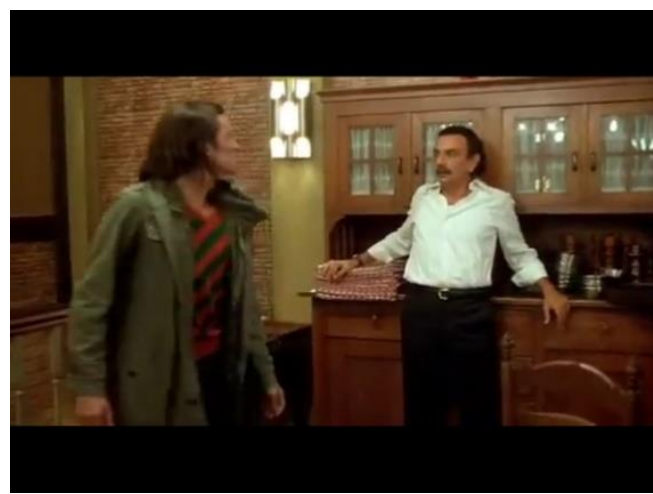

$(1: 33: 07)$

Adegan tersebut merupakan bentuk perlawanan Gigi yang terbesar terhadap ayahnya. Kali ini, ia melakukan agresi tidak pada objek sekitar Romano, melainkan ia melakukannya pada Romano. Ukuran knee shot digunakan untuk memfokuskan agresi yang dilakukan anak terhadap ayah. Oleh karena itu, perbuatan yang dilakukan Gigi menunjukkan bahwa karakternya berkembang semakin agresif seiring waktu.

Karena masalah keluarga yang tak kunjung usai, Gigi memutuskan untuk kembali ke Solino. Dalam tahap adaptasi suatu budaya dan lingkungan yang baru, tahap adaptasi dari setiap individu juga akan berpengaruh terhadap anggota keluarga yang lain. Tiap anggota keluarga Amato memiliki tahap adaptasi yang berbeda-beda ketika di Duisburg, Jerman. Hal ini bisa terlihat jelas dari masing-masing tokoh, yaitu Romano dan Giancarlo yang jelas tidak terikat dengan Solino sebagai rumahnya, sehingga ia terus menetap di Jerman. Sebaliknya, Rosa sangat terikat dengan Solino sebagai kampung halamannya. Ia tidak bisa beradaptasi walaupun sudah belasan tahun tinggal di Duisburg. Satu-satunya yang membuat ia bisa bertahan tinggal di sana adalah restorannya yang mengingatkannya pada Solino. Ketika Gigi pulang, Rosa yang menyambutnya memiliki perubahan, ia terlihat lebih sehat, berseri dan jauh lebih bahagia. Jika dibandingkan ketika di Jerman, lingkungan yang baru, tidak ramah dan Rosa yang sering mengalami konflik keluarga menyebabkan ia selalu terlihat lesu dan akhirnya jatuh sakit. Gigi pun kemudian mengalami hal serupa seperti Rosa. Ia awalnya lebih memilih untuk tinggal di Jerman karena ia ingin mengejar cita-citanya dalam industri film. Ketika Gigi kembali ke Solino, ia menemukan kenyamanan yang sesungguhnya yang tidak bisa ia dapat di Jerman. Lingkungan sosial yang hangat, masyarakat yang saling mengenal satu sama lain dan lingkungannya yang santai tidak bisa ia dapatkan di Jerman. Gigi bahkan menemukan cinta sejatinya yaitu Ada, teman masa kecil Gigi ketika di Solino.

10 tahun kemudian pada tahun 1984, Gigi dan Ada akhirnya menikah. Gigi mengundang Romano dan Giancarlo yang berada di Jerman. Giancarlo bisa hadir dalam pernikahan tersebut, sedangkan Romano tidak. Dalam adegan berikut, teknik kamera dolly back digunakan untuk menunjukkan Gigi dan Giancarlo yang sedang berjalan di gang.

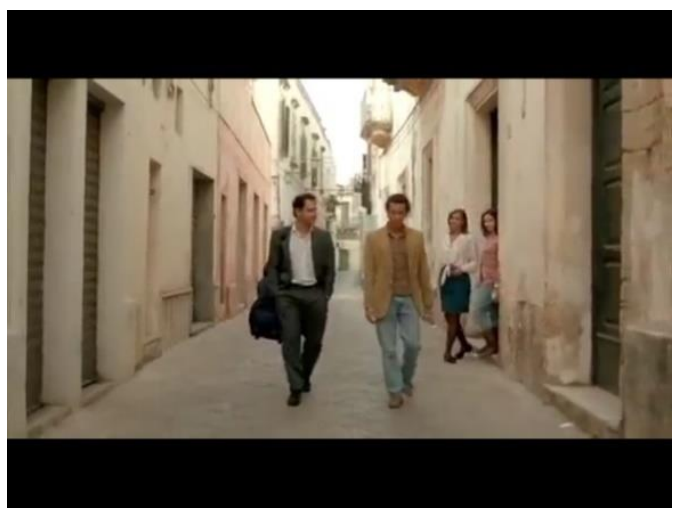

$(1: 46: 05)$

Ketika mereka berjalan, dua orang wanita memasuki frame lalu menyapa Gigi dan Giancarlo. Hal ini membuktikan bahwa lingkungan Solino merupakan lingkungan yang penduduknya dekat satu sama lain. Ketika mereka menikah, Gigi dan Ada sudah mempunyai dua anak. Anak-anak tersebut berlarian di pesta pernikahan kedua orang tuanya. 




$(1: 48: 28)$

Dalam adegan berikut, kamera menggunakan ukuran shot long shot untuk memberikan gambaran latar dan interaksi antar tokoh dalam frame tersebut. Dalam frame tersebut, anak dari Gigi yang bernama Paolo sedang berlari bersama anak-anak seusianya. Paolo kemudian diberhentikan secara lembut oleh Gigi dengan cara dirangkul dan diberi tahu secara lembut. Hal ini menunjukkan bahwa Gigi memiliki gaya pengasuhan yang berbeda dari Ayahnya, yaitu authoritative. Menurut teori gaya asuh dari Diana Baumrind, authoritative parents merupakan orang tua yang penuh kasih sayang dan sekaligus menetapkan batasan terhadap anak melalui diskusi. Orang tua dengan gaya asuh ini mendisiplinkan anaknya dengan perilaku positif alih-alih hukuman. Dalam adegan tersebut, dampak gaya asuh Gigi menjadikan Paolo anak yang bahagia dan dapat berinteraksi dengan teman sebaya dengan keterampilan sosial yang kompeten. Oleh karena itu, hal ini memperlihatkan bahwa gaya pengasuhan orang tua memainkan peranan yang besar terhadap perkembangan karakter anak.

\section{KESIMPULAN}

Film Solino menampilkan pemahaman terhadap masyarakat mengenai kehidupan berkeluarga dengan latar belakang keluarga migran. Dengan latar belakang sosial kultural yang bertolak belakang antara Italia dan Jerman, proses migrasi tersebut kemudian mempengaruhi identitas anggota keluarga Amato kelak. Pola pengasuhan sosok ayah dalam film ini menunjukkan gaya asuh yang otoriter. Romano meninggalkan citra yang kuat bahwa ia adalah ayah yang mendidik anak-anaknya dengan tegas dan sekaligus keras. Hasil analisis menunjukkan bahwa gaya asuh authoritarian yang digunakan tokoh ayah pada anak anak yang besar di wilayah Jerman yang egaliter, membuat tokoh anak memberontak secara frontal. Melalui film ini ditunjukan bahwa anak migrant tumbuh besar dalam lingkungan social dan budaya yang berbeda dari budaya asal, sehingga tokoh orang tua dituntut dapat menyesuaikan perubahan social budaya yang dihadapi.

Dalam selang waktu 30 tahun, kelanjutan film menunjukkan perkembangan identitas dan karakter dalam perjalanan hidup Gigi dan Giancarlo. Tahap adaptasi terhadap lingkungan baru menunjukkan Romano dan Giancarlo tidak terikat dengan Solino, sedangkan Rosa dan Gigi lebih terikat. Oleh karena itu, identitas Gigi dan Rosa sebagai orang Italia tidak berubah karena mereka memilih itu, sedangkan Giancarlo dan Romano terlihat membuang identitas tersebut dan memilih identitas barunya di Jerman. Budaya Italia dan Jerman digambarkan secara kontras. Italia digambarkan memiliki budaya yang konservatif sedangkan Jerman memiliki budaya yang lebih terbuka dan bebas. Dalam film ini, perkembangan karakter yang ditunjukkan antara lain adanya pergaulan bebas, peningkatan agresi, timbulnya masalah perilaku dan yang terakhir adalah kurangnya penghargaan pada diri sendiri. Selain itu, perkembangan karakter juga ditunjukkan ketika Gigi berkeluarga. Sebagai ayah, ia menolak melakukan pola pengasuhan otoriter dan menampilkan pola pengasuhan yang berbeda dari ayahnya, yaitu authoritative. Hasil dari gaya pengasuhan Gigi menunjukkan anaknya Paolo memiliki karakter yang percaya diri dan bahagia.

\section{REFERENSI}

Bedford, V., \& Turner, B. (Eds.). (2006). Men in relationships : A new look from a life course perspective. Retrieved from https://remotelib.ui.ac.id:2195

Benson, L. (1968). Fatherhood : A Sociological Perspective. New York: Random House. Brooks, J. B (1999). The Process of Parenting, $5^{\text {th }}$ Edition. California: Mayfield Publishing Company.

FilmSound.org. "Diegetic Sound - Non-diegetic Sound".

http://filmsound.org/terminology/diegetic.htm (diakses 20 Mei 2019)

Finkmeier, E. "A changed image of the 'immigrant' in German film? 'Sense of belonging' in Fatih Akin's "Solino" and "Gegen die Wand". https://remote-

lib.ui.ac.id:2155/docview/304982797?pqorigsite $=$ summon $($ diakses 20 April 2019)

Hall, Stuart. (1990). Cultural Identity and Diaspora. London: Framework Journal.

Larasati, A. "Relasi ayah dan anak dalam film Oorlogswinter 2008". http://lib.ui.ac.id/detail?id=20478868\&lokasi= lokal\#parentHorizontalTab2 (diakses 20 April 2019)

Marcia, J.E., et.al. (1993). Ego Identity : A Handbook for Psychological Research. Springer-Verlag, New York.

Parenting For Brain. "4 Parenting Styles Characteristics and Effects (Infographic) ". https://www.parentingforbrain.com/4baumrin d-parenting-styles/ (diakses 20 April 2019) 
Putra, A.R.S. "Challenging masculinity father figure in Disney Pixar's Finding Nemo". http://lib.ui.ac.id/detail?id=20460311\&lokasi= lokal\#parentHorizontalTab2 (diakses 20 April 2019)

Rahmawan, Y. "Anak 13 Tahun Diduga Jadi Korban Penganiayaan oleh Bapak Kandung". https://panturapost.com/anak-13-tahundiduga-jadi-korban-penganiayaan-oleh-bapakkandung/ (diakses 16 April 2019)

Scholastica, G. "73,7 Persen Anak Indonesia Mengalami Kekerasan di Rumahnya Sendiri”. https://tirto.id/737-persen-anak-indonesiamengalami-kekerasan-di-rumahnya-sendiricAnG (diakses 16 April)

Semedhi, B. (2011). Sinematografi-Videografi; Suatu Pengantar. Bogor: Penerbit Ghalia Indonesia.

Wijanarko, J \& Setiawati. E. 2016. “Ayah Baik - Ibu Baik: Parenting Era Digital, Pengaruh Gadgetdan Perilaku terhadap Kemampuan Anak'https://books.google.co.id/books?id=R GPADQAAQBAJ\&printsec $=$ frontcover $\& \mathrm{hl}=\mathrm{i}$ $\mathrm{d} \# \mathrm{v}=$ onepage $\& \mathrm{q} \& \mathrm{f}=$ false $\quad($ diakses 19 April 2019 Pukul 02:14).

\section{PROFIL PENULIS}

Ardenia Edianti adaah alumni program studi Jerman Fakultas Ilmu Pengetahuan Budaya UI yang lulus pada tahun 2019. Bidang penelitian yang digeluti adalah sastra dan budaya, khususnya terkait isu parenting dalam perspektif interkultural.

Lisda Liyanti adalah dosen aktif pada program studi Jerman Fakultas Ilmu Pengetahuan Budaya UI. Lulus dari Prodi Jerman pada tahun 2006, kemudian melanjutkan program master atas beasiswa Erasmus Mundus-Uni Eropa pada Crossways in European Humanities di Universitet Tuebingen Jerman. Area risetnya meliputi bidang sastra dan budaya, khususnya pada kajian anak \& gender, ruang, identitas, dan multicultural. 